\title{
Adjustment of Phosphorus Concentration to Increase Growth and Yield of Cherry Tomato Using Hydroponic Drip System
}

\section{Pengaturan Konsentrasi Fosfor untuk Meningkatkan Pertumbuhan dan Hasil Tanaman Tomat Cherry pada Sistem Hidroponik Irigasi Tetes}

\author{
Cecep Hidayat, Budy Frasetya, Ilman N. Syamsudin
}

Agrotechnology Department, UIN Sunan Gunung Djati, A.H. Nasution 105 Street, Bandung 40614, Indoneisa

Correspodence: cephidayat62@uinsgd.ac.id

Accepted November, $27^{\text {th }}$ 2018/ Approved December, $28^{\text {th }} 2018$

\begin{abstract}
The phosphorus element plays an essential role in plant growth both at the vegetative and generative phases, so its concentration modification in the nutrient solution is necessary to stimulate vegetative growth and crop yield. The research aimed to know the influence of different phosphorus concentrations on growth and yield of cherry tomato using a hydroponic drip irrigation system, conducted from February to June 2017 at Green House Research Station of Universitas Padjajaran Jatinangor using Completely Randomized Design with five treatments and five replications. The treatments were: phosphorous concentration of $100 \mathrm{ppm}(\mathrm{P} / \mathrm{N}$ ratio 0.4$), 125 \mathrm{ppm}$ ( $\mathrm{P} / \mathrm{N}$ ratio 0.5$), 150 \mathrm{ppm}(\mathrm{P} / \mathrm{N}$ ratio 0.6$), 175 \mathrm{ppm}$ (P/N ratio 0.7), and $200 \mathrm{ppm}(\mathrm{P} / \mathrm{N}$ ratio 0.8). The results showed that the increasing concentration of phosphorus improved crops height at the end of the vegetative phase, increased the number of flowers from the beginning to the end of the generative period, was able to prevent the flower fall, enhanced harvest index and weight of tomato fruit significantly at harvest time. Application of $200 \mathrm{ppm}$ phosphorus concentration can increase growth and yield of cherry tomato.
\end{abstract}

Key words : Cherry tomato, concentrations, drip irrigation, hydroponic, phosphorus

\section{ABSTRAK}

Unsur fosfor berperan penting dalam pertumbuhan tanaman pada fase vegetatif maupun fase generatif. Konsentrasi unsur $\mathrm{P}$ pada nutrisi tanaman sangat penting untuk merangsang pertumbuhan vegetatif dan hasil panen. Penelitian ini bertujuan untuk mengetahui pengaruh ragam kosentrasi unsur posfor terhadap pertumbuhan dan hasil tanaman tomat cherry pada sistem hidroponik irigasi tetes. Penelitian telah dilaksanakan pada bulan Februari sampai Juni 2017 di Green House Universitas Padjadjaran Jatinangor menggunakan rancangan acak lengkap terdiri dari lima perlakuan dan lima ulangan. Perlakuan konsentrasi posfor, yaitu 100 ppm (rasio P/N 0,4), 125 ppm (rasio P/N 0,5), 150 ppm (rasio P/N 0,6); 175 ppm (rasio P/N 0,7), dan 200 ppm (rasio P/N 0,8). Hasil penelitian menunjukkan bahwa peningkatan konsentrasi posfor meningkatkan tinggi tanaman pada akhir fase vegetatif, meningkatkan jumlah bunga dari awal sampai akhir fase generatif, mengurangi jumlah bunga gugur, meningkatkan indeks panen dan berat buah. Aplikasi konsentrasi posfor 200 ppm dapat meningkatkan pertumbuhan dan hasil tanaman tomat cherry.

Kata kunci: Hidroponik, irigasi tetes, konsentrasi, tomat cherry, unsur posfor

Cite this as: Hidayat, C. Frasetya. B. \& Syamsudin, I. N. (2018). Adjustment of phosphorus concentration to increase growth and yield of cherry tomato using hydroponic drip system. Jurnal Agro, 5(2), 140-147. https://doi.org/10.15575/3658 


\section{INTRODUCTION}

Cherry tomato is a horticultural product which is popular among middle up communities in the major cities of Indonesia and only retrieved at the supermarket. The people like this fruit vegetable because of its performance; the red colour and small size, plus the taste is sweeter in comparison with the big tomato. To meet quantity and quality aspects, this crop cultivation can be done in green house with hydroponic systems ( $\mathrm{Wu} \&$ Kubota, 2008). Hydroponic system in a controlled environment makes production of cherry tomato fruit to be maximum, because management of water and nutrient elements correspond with the needs of the plants (Hidayat et al., 2018). A nutrient solution is delivered at the base of the plant with sufficient volume.

Temperature, EC, and nutrients influence the success of cherry tomato plant growth in hydroponic system (Herrero et al., 2014). Phosphorus is the macro nutrient that plays important role in plant metabolism. Phosphorus is part of the essential process of photosynthesis and carbohydrate metabolism functioning as regulator of photosynthate partition between the source and the reproductive organs (Reshma \& Sarath, 2017). One of the difficulties in hydroponic cultivation is not yet known concentrations of optimal nutrient elements for plant growth. At too low dosage, it results non-significant effect, whereas at too high dosage it becomes waste and the plant undergoes plasmolysis, the cell fluid is discharged because it is attracted by more concentrated nutrient solution (Wortman, 2015).

The concentration of phosphorus will determine the number of element in a nutrient solution. Research of Wijayani \& Widodo (2005), which compared the growth of tomato plants by using two different types of nutrients $\mathrm{P} / \mathrm{N} 0.4$ ( $\mathrm{P}=80$ ppm; $\mathrm{N}=180$ ppm) and $\mathrm{P} / \mathrm{N} 0.97$ ( $\mathrm{P}=321 \mathrm{ppm} ; \mathrm{N}=330 \mathrm{ppm})$, obtained that the different nutrients ratio $P / N$ influence the tomato fruit yield. Plants with treatment formulations the ratio $\mathrm{P} / \mathrm{N} \quad 0.4$ generated more numbers of tomato that is directly proportional to the tomato fruit yield. According to Mason (2014) recommendation $P$ concentration for tomato nutrient between 20-200 ppm; N-total concentration 50-300 ppm and $\mathrm{P} / \mathrm{N}$ ratio $0.4-0.67$. Optimum hydroponic nutrient for tropical and sub tropical differs from one place to another (Resh, 2013). Optimum concentration of $P$ requirement for tomato is not certainly known. Based on the description above concentration of element $P$ offered up from $100 \mathrm{ppm}$ to $200 \mathrm{ppm}$ with the ratio P/N 0.40.8. Expected that with increased of element $P$, the plant growth, the number of flowers, and fruit yield of tomato can be improved.

The aim of the research was to find out the effect of different phosphorus concentrations on growth and yield of cherry tomato cultivar Tropical Ruby using hydroponic drip irrigation system.

\section{MATERIALS AND METHODE}

A greenhouse trial at Green House Research Station of Universitas Padjadjaran at $734 \mathrm{~m}$ above sea level was carried out from March to June 2017. Materials used were cherry tomato seed cultivar Tropical Ruby, AB MIX fertilizer consisted of chemical compound A $\left(\mathrm{CaNH}_{4} \cdot \mathrm{NO}_{3}, \mathrm{KNO}_{3}, \mathrm{BMX}\right)$ and chemical compound B $\left(\mathrm{KH}_{2} \mathrm{PO}_{4}, \mathrm{~K}_{2} \mathrm{SO}_{4}, \mathrm{MgSO}_{4} \cdot \mathrm{H}_{2} \mathrm{O}\right)$, formulation nutrient in ppm units $(\mathrm{N}=250$; $\mathrm{Ca}=250 ; \mathrm{K}=450 ; \mathrm{Mg}=100 ; \mathrm{S}=221 ; \mathrm{Fe}=1.6$; $\mathrm{Mn}=0.85 ; \mathrm{Zn}=0.3 ; \mathrm{B}=0.44 ; \mathrm{Mn}=0.01$ ); polybag $40 \times 40 \mathrm{~cm}$, drip irrigation installation consisted of: PVC $3 / 4$ inch for primer pipe, PVC $1 / 2$ inch for secondary pipe, and PVC $1 / 2$ inch tertiary pump, water pump 18 watt, ECmeter, and $\mathrm{pH}$-meter. 
The experiment used Completely Randomized Design with five treatments and five replications. The treatments were: phosphorous concentration of $100 \mathrm{ppm}(\mathrm{P} / \mathrm{N}$ ratio 0.4$), 125 \mathrm{ppm}(\mathrm{P} / \mathrm{N}$ ratio 0.5$), 150 \mathrm{ppm}$ $(\mathrm{P} / \mathrm{N}$ ratio 0.6$), 175 \mathrm{ppm}(\mathrm{P} / \mathrm{N}$ ratio 0.7$)$ as standard, and $200 \mathrm{ppm}$ (P/N ratio 0.8 ).

Cherry tomato seedlings 14 days were planted on polybag containing a mixture of charcoal and husk (1:1 v/v). Continue and periodic fertigation flew through pipe and emitter to deliver water and fertilizer to the root. Water applied was $25 \mathrm{~mm} \cdot \mathrm{dec}^{-1}$ or 900 $\mathrm{mL} . \mathrm{crop}^{-1} \cdot \mathrm{day}^{-1}$ at 0-70 Days After Transplanting (DAT), $40 \mathrm{~mm} \cdot \mathrm{dec}^{-1}$ or 1.440 $\mathrm{mL} . \mathrm{crop}^{-1} \cdot$ day $^{-1}$ at 71 DAT harvest with watering interval was three times a day at 7 am, 11 am and $2 \mathrm{pm}$. Fertilization used fertilizer A and fertilizer B (Phosporous element concentration adjusment according to the treatment by adjusting $\mathrm{KH}_{2} \mathrm{PO}_{4}$ ) which had been dissolved in $5 \mathrm{I}$ of water separately and blended at the time the fertilizer would be given in accordance with a concentration of treatments. EC values were $1.2 \mathrm{mS}$, at seedling period, $2.0 \mathrm{mS} . \mathrm{cm}^{-1}$ at vegetative phase or 14-50 days after planting (DAT) with $\mathrm{pH} 6.3-6.5$, and $3.5 \mathrm{mS} \mathrm{cm}^{-1}$ with $6.0-6.3$ $\mathrm{pH}$ at generative phase or when crops started to flowering at 50 DAT (Resh, 2013). Average air temperature was $32^{\circ} \mathrm{C}$, maximum temperature was $38^{\circ} \mathrm{C}$ and minimum temperature was $26^{\circ} \mathrm{C}$ and $\mathrm{RH}$ was $70-90 \%$.

The parameters observed were plant height $(\mathrm{cm})$ measured weekly from 1-8 Weeks After Transplanting (WAT), the number of flower at 10,11,12, and 13 WAT, flower fall at 13 WAT, and weight (g) of tomato was calculated at the time of harvest. To analyse the data, F Test at $5 \%$ level was used and continued with Duncan Multi Range Test at $5 \%$ level.

\section{RESULT AND DISCUSSION}

\section{Climatic Condition at Experimental Sites}

The result of observation climatic condition showed that daily average temperature was $31.28^{\circ} \mathrm{C}$ and daily average humidity was $82,69 \%$ (Figure 1). According to Aprile \& Lorandi (2012) the tropical regions have relatively constant daily temperatures throughout the year. Temperature and humidity fluctuations are determined by solar radiation and rainfall. The optimum temperatures for tomato according to Herrero et al. (2014) is $24-26^{\circ} \mathrm{C}$ at the daytime and 18$20^{\circ} \mathrm{C}$ at night.

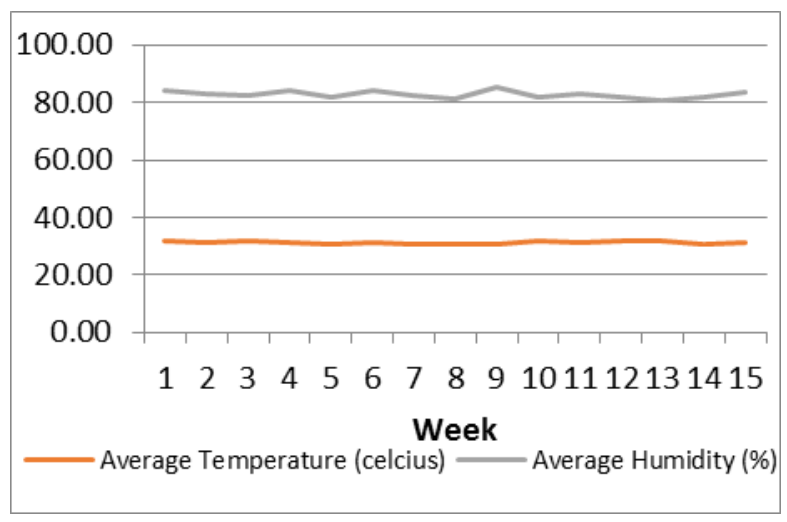

Figure 1. Average Weekly Temperature and Average Weekly Humidity at Greenhouse

\section{Plant Height}

Application of different phosphorus concentrations gave no significant effect on plant height at initial vegetative phase $(1,2,3$, 4 week after transplanting (WAT) and showed significant effect on plant height at 5, 6, 7 and 8 WAT or at the end of vegetative phase (Table 1).

The data from Table 1 showed that an increasing of phosphorus concentration had no effect on plant height at initial stage of vegetative phase due to the plants were still in adaptation to environment and could not absorb the nutrient maximally (Hidayat et al., 2018). The plant began to respond on 
different phosphorus concentration starting from 5 WAT. Increasing of phosphorus concentration enhanced plant height until the end of vegetative phase. Application of phosphorus 175 ppm and 200 ppm showed the highest plant height, i.e. $166.6 \mathrm{~cm}$ and $164.6 \mathrm{~cm}$ where the value were in the range of tomato variety Cherry Ruby height potency i.e. $150-300 \mathrm{~cm}$.

Table 1. Effect of Different Phosphorus Concentrations on Plant Height

\begin{tabular}{cccccccc}
\hline Phosphorus & \multicolumn{7}{c}{ Plant Height $(\mathrm{cm})$} \\
\cline { 2 - 7 } Concentrations & 1 WAT & 2 WAT & 3 WAT & 4 WAT & 5 WAT & 6 WAT & 7 WAT \\
\hline A $(\mathrm{P}=100 \mathrm{ppm})$ & $16.0 \mathrm{a}$ & $29.2 \mathrm{a}$ & $42.8 \mathrm{a}$ & $64.2 \mathrm{a}$ & $82.4 \mathrm{ab}$ & $114.6 \mathrm{a}$ & $141.2 \mathrm{a}$ \\
$\mathrm{B}(\mathrm{P}=125 \mathrm{ppm})$ & $16.8 \mathrm{a}$ & $29.4 \mathrm{a}$ & $45.2 \mathrm{a}$ & $73.6 \mathrm{a}$ & $88.2 \mathrm{abc}$ & $117.2 \mathrm{a}$ & $142.0 \mathrm{a}$ \\
$\mathrm{C}(\mathrm{P}=150 \mathrm{ppm})$ & $15.6 \mathrm{a}$ & $27.6 \mathrm{a}$ & $46.0 \mathrm{a}$ & $66.8 \mathrm{a}$ & $78.2 \mathrm{a}$ & $121.0 \mathrm{ab}$ & $153.2 \mathrm{ab}$ \\
$\mathrm{D}(\mathrm{P}=175 \mathrm{ppm})$ & $15.0 \mathrm{a}$ & $31.2 \mathrm{a}$ & $44.2 \mathrm{a}$ & $73.2 \mathrm{a}$ & $103.4 \mathrm{c}$ & $134.8 \mathrm{~b}$ & $166.6 \mathrm{~b}$ \\
$\mathrm{E}(\mathrm{P}=200 \mathrm{ppm})$ & $16.0 \mathrm{a}$ & $29.4 \mathrm{a}$ & $41.4 \mathrm{a}$ & $72.6 \mathrm{a}$ & $97.4 \mathrm{bc}$ & $138.2 \mathrm{~b}$ & $164.6 \mathrm{~b}$ \\
\hline
\end{tabular}

Remarks : Numbers followed by same letter are not significantly different based on Duncan's Multiple Range Test at $5 \%$ level

The difference of height plant due to application of difference phosphorus concentration is closely related with the role of $P$ in the formation of new cells at the meristematic tissue. Grennan (2008) found that phosphorus required by plants for the formation of cellular compounds so that the treatment with the highest $\mathrm{P}$ concentration showed better results in plant height. In accordance with research Aldana (2005) an increasing of phosphorus concentration in chilli plants given in hydroponics significantly increased plant height and stem diameter because it related to the function of $P$ which is fundamental in the process of photosynthate distribution to plant vegetative organs.

\section{Number of Flowers}

Application of different phosphorus concentrations significantly increased the number of flowers since the beginning of generative phase. The more phosphorus concentrations, the more the number of flowers (Table 2).

Table 2. Effect of Different Phosphorus Concentrations on Number of Flowers

\begin{tabular}{ccccc}
\hline \multirow{2}{*}{ Phosphorus Concentrations } & \multicolumn{4}{c}{ Number of Flowers } \\
\cline { 2 - 5 } & $10 \mathrm{WAT}$ & 11 WAT & 12 WAT & 13 WAT \\
\hline $\mathrm{A}(\mathrm{P}=100 \mathrm{ppm})$ & $75.1 \mathrm{a}$ & $99.1 \mathrm{a}$ & $125.6 \mathrm{a}$ & $149.2 \mathrm{a}$ \\
$\mathrm{B}(\mathrm{P}=125 \mathrm{ppm})$ & $78.5 \mathrm{ab}$ & $101.1 \mathrm{a}$ & $132.1 \mathrm{a}$ & $166.9 \mathrm{~b}$ \\
$\mathrm{C}(\mathrm{P}=150 \mathrm{ppm})$ & $92.6 \mathrm{abc}$ & $112.8 \mathrm{ab}$ & $132.1 \mathrm{a}$ & $166.1 \mathrm{~b}$ \\
$\mathrm{D}(\mathrm{P}=175 \mathrm{ppm})$ & $102.2 \mathrm{bc}$ & $129.5 \mathrm{bc}$ & $161.2 \mathrm{~b}$ & $197.1 \mathrm{c}$ \\
$\mathrm{E}(\mathrm{P}=200 \mathrm{ppm})$ & $116.5 \mathrm{c}$ & $150.3 \mathrm{c}$ & $179.7 \mathrm{~b}$ & $218.4 \mathrm{c}$ \\
\hline
\end{tabular}

Remarks : Numbers followed by same letter are not significantly different based on Duncan's Multiple Range Test at $5 \%$ level

The results showed that increasing the concentration of $\mathrm{P}$ until $175 \mathrm{ppm}$ or $200 \mathrm{ppm}$ starting at 12 and 13 WAT have a number of flowers was formed. This data in line with Nowaki et al. (2017) who found that the optimum $\mathrm{P}$ can increase some of the reproductive properties of the plants in the form of total mass of flowers, fruit production, and number of seed production of pollen per plant. Phosphorus plays a role in 
increasing the photosynthetic reaction in plants (Gad \& Kandil, 2010).

In conditions of optimum photosynthetic, photosynthate resulted by plants is higher and correlates positively with cell division at the plant as a whole and can therefore stimulate flowering plants and the flowers produced are more in line with the higher $P$ concentrations (Basirat et al., 2011). Optimum P concentration also affect healthy root growth which helps water and nutrient uptake by the plant (Fandi et al., 2010).

\section{Flower Fall}

Application of different phosphorus concentrations succeeded to prevent flower fall at 13 WAT. Application of higher phosphorus concentration starting of 175 ppm prevented $86.50 \%$ flower fall comparing with a phosphorus concentration of $100 \mathrm{ppm}$ prevented $60.99 \%$ (Table 3).

Based on Table 3, the highest flower fall occurred in tomato plants treated with low phosphorus concentration of 100 and 125 ppm and decreased in line with increasing of phosphorus concentration. Flower fall correlates with photosynthate availability. Flower fall especially affect by water stress. According to Fandi et al. (2010) high concentration of phosphorus has possitive role in affect root growth. Healthy root in tomato has effect to optimum water uptake by plant. Therefore, optimum water uptake can reduce flower fall of tomato.

Table 3 Effect of Different Phosphorus Concentrations on Flower Fall

\begin{tabular}{cc}
\hline Phosphorus Concentrations & Flower Fall (\%) \\
\hline$A(P=100 p p m)$ & $39.01 \mathrm{c}$ \\
$B(P=125 \mathrm{ppm})$ & $35.23 \mathrm{c}$ \\
$\mathrm{C}(\mathrm{P}=150 \mathrm{ppm})$ & $22.64 \mathrm{~b}$ \\
$D(P=175 \mathrm{ppm})$ & $13.50 \mathrm{a}$ \\
$\mathrm{E}(\mathrm{P}=200 \mathrm{ppm})$ & $11.72 \mathrm{a}$ \\
\hline
\end{tabular}

Remarks : Numbers followed by same letter are not significantly different based on Duncan's Multiple Range Test at $5 \%$ level

According to Krishnan et al. (2014) increasing fruit set and flowering of tomato flower fall might be due to sufficient plant nutrients supply. Phosphorus plays a role in increasing the photosynthetic reaction in plants (Gad \& Kandil, 2010) in energy transfer and thus influences the photosynthate.

\section{Harvest Index}

Application of different phosphorus concentrations enhanced Harvest Index. Application of phosphorus starting from 175 ppm significantly increased Harvest Index and the concentration of phosphorus 200 ppm showed the highest Harvest Index (Table 4).

Table 4 Effect of Different Phosphorus Concentrations on Harvest Index

\begin{tabular}{cc}
\hline Phosphorus Concentrations & Harvest Index \\
\hline$A(P=100 p p m)$ & $0.53 \mathrm{ab}$ \\
$B(P=125 \mathrm{ppm})$ & $0.48 \mathrm{a}$ \\
$\mathrm{C}(\mathrm{P}=150 \mathrm{ppm})$ & $0.57 \mathrm{~b}$ \\
$\mathrm{D}(\mathrm{P}=175 \mathrm{ppm})$ & $0.66 \mathrm{c}$ \\
$\mathrm{E}(\mathrm{P}=200 \mathrm{ppm})$ & $0.81 \mathrm{~d}$ \\
\hline Remarks : Numbers followed by same letter are not significantly different based on Duncan's Multiple Range \\
Test at 5\% level
\end{tabular}


According to Nowaki et al. (2017) that the lower the concentration of $P$ applied on tomato plants lead to a decrease on plants dry weight in general so that the lower plants dry weight produced mainly fruit, resulting lower harvest index values.

Decreasing of $\mathrm{P}$ element on tomato cultivation in hydroponics leads to decrease activity of plant growth and development as well as a reduction in the production of biomass by the roots and shoot plants (Chang \& Lee, 2015).

\section{Weight of Tomato Fruit}

Application of different phosphorus concentrations influenced weight of tomato fruit per plant at the harvest time. The highest weight of tomato fruit per plant was obtained by application of phosphorus 200 ppm (Table 5).

Table 5. Effect of Different Phosphorus Concentrations on Weight of Tomato Fruit

\begin{tabular}{cc}
\hline Phosphorus Concentrations & Weight of Tomato Fruit per Plant $(g)$ \\
\hline$A(P=100 p p m)$ & $829.8 \mathrm{a}$ \\
$B(P=125 \mathrm{ppm})$ & $846.2 \mathrm{a}$ \\
$C(P=150 \mathrm{ppm})$ & $995.8 \mathrm{~b}$ \\
$D(P=175 \mathrm{ppm})$ & $1119.6 \mathrm{c}$ \\
$\mathrm{E}(\mathrm{P}=200 \mathrm{ppm})$ & $1393.2 \mathrm{~d}$ \\
\hline
\end{tabular}

Remarks : Numbers followed by same letter are not significantly different based on Duncan's Multiple Range Test at $5 \%$ level

In accordance with research of Cole et al. (2016) the influence of fertilizer $P$ in the growth and yield of tomato increased total weight per plant on higher $\mathrm{P}$ application. The $P$ concentration of $200 \mathrm{ppm}$ prevented flower fall lower percentage and increased harvest index, so that fruit set on $200 \mathrm{ppm}$ of $\mathrm{P}$ concentration has positive role on fresh weight of tomato fruit. Youssef \& Eissa (2017) found the same thing, increase the number of $P$ in a nutrient solution which is applied on tomato plants in a hydroponic produced high fresh and dry weight of tomato fruit. This data in line with all data measured such as plant hegiht, number of the flowers, flower fall, and harvest index that showed increasing of $P$ concentration increased all parameters and finally produced highest weight of tomato fruit per plant.

\section{CONCLUSION}

Concentration of phosphorus 200 ppm $(\mathrm{P} / \mathrm{N}$ ratio 0.8$)$ improved crops growth and yield of cherry tomato.

\section{Acknowledgements}

This work was supported by dean the faculty of science and technology, head of Agrotechnology Department UIN Sunan Gunung Djati Bandung, and all parties for their contributions in conducting the experiment

\section{REFERENCES}

Aldana, M. E. (2005). Effect of phosphorus and potassium fertility on fruit quality. LSU Master's Theses. Lousiana State University. Retrieved from http://digitalcommons.lsu.edu/gradscho ol_theses

Aprile, F., \& Lorandi, R. (2012). Evaluation of cation exchange capacity ( CEC) in tropical soils using four different analytical methods. Journal of Agricultural Science, 4(6), 278-289. https://doi.org/10.5539/jas.v4n6p278

Basirat, M., Malboobi, M. A., Mousavi, A., Asgharzadeh, A., \& Samavat, S. (2011). Effects of phosphorous supply on 
growth, phosphate distribution and expression of transporter genes in tomato plants. Australian Journal of Crop Science, 5(5), 537-543.

Chang, D. C., \& Lee, Y. B. (2015). Response of potatoes to different nutrient solution management in a closed hydroponic system. Journal of Plant Nutrition, 4167(May), 00-00. https://doi.org/10.1080/01904167.2015. 1109120

Cole, J. C., Smith, M. W., Penn, C. J., Cheary, B. S., \& Conaghan, K. J. (2016). Nitrogen, phosphorus, calcium, and magnesium applied individually or as a slow release or controlled release fertilizer increase growth and yield and affect macronutrient and micronutrient concentration and content of fieldgrown tomato plants. Scientia Horticulturae, 211, 420-430. https://doi.org/10.1016/j.scienta.2016.0 9.028

Fandi, M., Muhtaseb, J., \& Hussein, M. (2010). Effect of $\mathrm{N}, \mathrm{P}, \mathrm{K}$ concentrations on yield and fruit quality of tomato (Solanum lycopersicum L.) in tuff culture. Journal of Central European Agriculture, 11(2), 179-184.

Gad, N., \& Kandil, H. (2010). Influence of cobalt on phosphorus uptake, growth and yield of tomato. Agriculture and Biology Journal of North America, 1(5), 1069-1075. https://doi.org/10.5251/abjna.2010.1.5. 1069.1075

Grennan, A. K. (2008). Phosphate Accumulation in Plants: Signaling. Plant Physiology, 148(1), 3-5. https://doi.org/10.1104/pp.104.900269

Herrero, B., Blázquez, M. E., \& Cristóbal, M. D. (2014). Nutrient levels in a productive cycle of hydroponic tomato crop. Bulgarian Journal of Agricultural Science, 21(1), 160-166.
Hidayat, C., Pahlevi, M. R., Taufiqqurahman, B. F., \& Ramdhani, M. A. (2018). Growth and yield of chili in nutrient film technique at different electrical conductivity. IOP Conference Series: Materials Science and Engineering, 288(1). https://doi.org/10.1088/1757899X/288/1/012034

Krishnan, A., Indiresh, K. M., \& Anjanappa, M. (2014). Effect of water soluble fertilizers on growth and yield of tomato ( Solanum lycopersicum L .). Journal of Tropical Agriculture, 52(2), 154-157.

Mason, J. (2014). Commercial Hydroponics (3rd ed.). Tennessee: Kangaroo Press.

Nowaki, R. H. D., Parent, S.-É., Cecílio Filho, A. B., Rozane, D. E., Meneses, N. B., Silva, J. A. dos S. da, Parent, L. E. (2017). Phosphorus over-fertilization and nutrient misbalance of irrigated tomato crops in Brazil. Frontiers in Plant Science, 8(May), 1-11. https://doi.org/10.3389/fpls.2017.00825

Resh, H. M. (2013). Hydroponic food production (7th ed.). New York: CRS Press.

Reshma, T., \& Sarath, P. S. (2017). Standardization of growing media for the hydroponic cultivation of tomato. International Journal of Current Microbiology and Applied Sciences, 6(7), 626-631.

Wijayani, A., \& Widodo, W. (2005). Increasing of tomatoes quality in hydroponic culture. Ilmu Pertanian, 12(1), 77-83.

Wortman, S. E. (2015). Crop physiological response to nutrient solution electrical conductivity and $\mathrm{pH}$ in an ebb-and-flow hydroponic system. Scientia Horticulturae, 194, 34-42. https://doi.org/10.1016/j.scienta.2015.0 7.045

Wu, M., \& Kubota, C. (2008). Effects of high electrical conductivity of nutrient 
solution and its application timing on lycopene, chlorophyll and sugar concentrations of hydroponic tomatoes during ripening. Scientia Horticulturae, 116, 122-129. https://doi.org/10.1016/j.scienta.2007.1 1.014

Youssef, M. A., \& Eissa, M. A. (2017). Comparison between organic and inorganic nutrition for tomato. Journal of Plant Nutrition, 40(13), 1900-1907. https://doi.org/10.1080/01904167.2016. 1270309 